\title{
Editorial
}

\section{O que quer um editor?}

\section{Editorial}

\section{What does an Editor Want?}

\author{
Regina Horta DUARTE \\ Editora Chefe de Varia Historia \\ Universidade Federal de Minas Gerais \\ Av. Antônio Carlos 6627, Belo Horizonte, MG, 31.270-901, Brasil \\ reginahortaduarte@gmail.com
}

Sigmund Freud, brilhante pensador e pai da psicanálise, se declarou incapaz de resolver a pergunta "o que quer uma mulher". Talvez porque nem todas as mulheres queiram a mesma coisa... Muito mais fácil é saber o que quer um editor de periódico acadêmico. Mesmo assim, muitos autores submetem artigos de forma equivocada, resultando muitas vezes em perda de tempo para todos e até no insucesso da submissão.

Uma vez que um pesquisador termine seu artigo, e pense num veículo para divulgar o conhecimento que produziu, é importante escolher uma revista cuja missão tenha real afinidade com o texto proposto. Mais do que algumas linhas formais, uma revista tem em sua missão o seu norte, e segui-lo garante coerência, além de ser um primeiro passo para obter credibilidade entre seus leitores.

Navegar pelo site da revista é sempre esclarecedor no que diz respeito a aspectos importantes das práticas de edição. Muitas revistas publicam suas normas éticas, e ali é possível estimar expectativas em termos de originalidade, ineditismo, autoria, etc. Outro procedimento útil é folhear alguns números recém-publicados, avaliar a revista "em funcionamento",

http://dx.doi.org/10.1590/0104-87752017000200001

Varia Historia, Belo Horizonte, vol. 33, n. 62, p. 301-303, mai/ago 2017 
nos seus aspectos gerais, como qualidade das edições, padronização, pontualidade, prazos entre submissão e publicação, entre outros.

Se o artigo se afina com a missão e com o escopo geral da revista, o autor deve estar aberto ao diálogo com os editores desde o preparo da versão a ser apresentada. Cada revista tem suas regras de submissão: extensão do artigo, formas de citação dos documentos e bibliográfica, orientação para inclusão de imagens. Como a maioria das revistas lida com processos anônimos de revisão por pares, é importante ocultar não apenas o nome do autor, mas também notas de rodapé que, de alguma forma, denunciem autoria, agradecimentos, autocitações. Cegar o artigo adequadamente é uma gentileza com o editor e, especialmente, com os pareceristas, que se sentirão constrangidos ao descobrir a autoria no meio da leitura de um texto, após terem declarado impedimento ético.

Revistas acadêmicas demandam ineditismo. E ineditismo supõe que o leitor encontrará ali um argumento, ideias e conclusões que ele não encontra em nenhum outro texto. O editor quer zelar por seus leitores, e empenhou sua palavra de que os artigos publicados valem a pena de serem lidos. Ele quer cumprir essa promessa.

Os abstracts e palavras-chave não são uma mera formalidade. Eles são essenciais na divulgação do artigo. Assim, abstracts traduzidos para o inglês pelo Google tradutor são desanimadores, e constam negativamente no processo inicial de julgamento. Enfim, parece que o próprio autor não leva seu artigo a sério.

Finalmente, é importante que o autor saiba achar o momento certo para enviar seu texto. Resultados ainda muito parciais de pesquisa podem não ser tão relevantes para os pesquisadores do tema, e o interesse da revista levará o editor a escolher artigos com resultados mais consistentes e argumentos mais amadurecidos.

Editores zelam pelos processos de julgamento por pares. E esperam que revisores sejam realmente críticos e exigentes, sempre preservando a gentileza. Mas é importante também que os autores estejam dispostos a ouvir sugestões e exigências, tomando a revisão como oportunidade para melhorar seu artigo. 
Enfim, há aqui um diálogo acadêmico que precede os diálogos que o artigo estabelecerá, assim que for a público. Tantos trâmites demandam esforços de todas as partes, e trazem amadurecimento e valiosos aprendizados. E assim, o editor tem seu maior desejo realizado: oferecer uma nova revista com bons artigos, por em circulação conhecimento de qualidade, sempre em prol da transformação do nosso entendimento do mundo. 